\title{
HET BELANG VAN HET KIND
}

In de rubriek Geregeld leggen wij het vergrootglas op wet- en regelgeving. Mr. Alice Broersma verheldert onderwerpen die voor niet-juristen soms taaie kost zijn, of bespreekt juridische thema's die actueel zijn in ons werkveld.
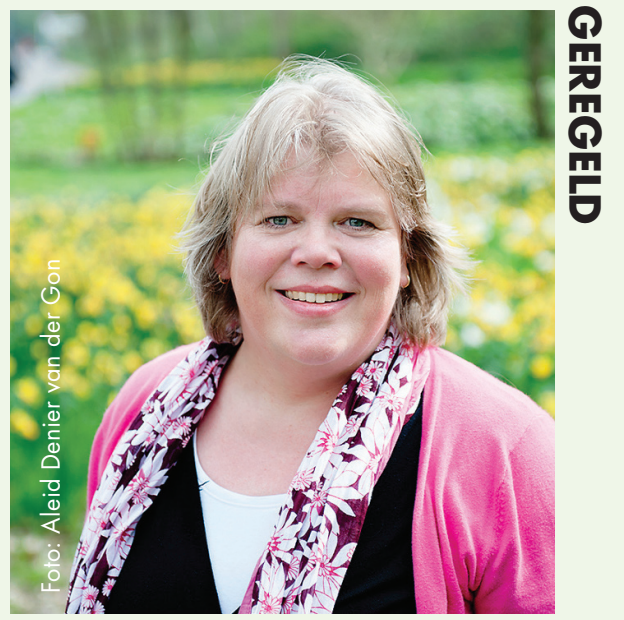

eugdhulpverleners worden geacht de zorg van een goed hulpverlener in acht te nemen. Zij moeten in het belang van het kind handelen. Maar hoe bepaal je dat belang van het kind? Dat is in de genoemde wetten niet concreet of zwart-wit ingevuld. Wat het belang van het kind is, hangt af van omstandigheden in het individuele geval. Het belang van het kind moet goed worden onderbouwd, bijvoorbeeld als er zorgen zijn over kinderen. Ik gebruik daarvoor regelmatig het boekje van Margrite Kalverboer en Elianne Zijlstra. Zij schreven in 2006 Het belang van het kind in het Nederlands recht, Voorwaarden voor ontwikkeling vanuit een pedagogisch perspectief. Daarin vind je een overzicht van condities waaraan de omgeving van een kind moet voldoen om een optimale ontwikkeling zoveel mogelijk te waarborgen. De ontwikkelingscondities zijn:

1. Adequate verzorging. Denk aan zorg voor de gezondheid en het welzijn van het kind, voeding, kleding, onderkomen, persoonlijk eigendom, voldoende inkomen in het gezin en ouders die daarover geen zorgen ervaren.

\section{Een veilige fysieke omgeving} waarin er geen geweld of (levens) bedreigende omstandigheden zijn in de directe omgeving van het kind. 3. Stabiliteit en continuïteit in opvoeding en verzorging en in levensomstandigheden, en waarbij sprake is van een toekomstperspectief. Hechting, basisvertrouwen door beschikbaarheid van een ouder, enige voorspelbaarheid en de aanwezigheid van identificatiefiguren en steunbronnen.

4. Interesse bestaande vit het tonen van belangstelling voor het kind en zijn leefwereld door de ouder.

5. Respect: de behoeften, wensen, gevoelens en verlangens van het kind worden serieus genomen door de omgeving van het kind.

6. Geborgenheid, steun en begrip. Er is een affectief klimaat waarbij sprake is van geborgenheid, steun en begrip vanuit de omgeving voor het kind. 7. Een ondersteunende flexibele structuur waarbii voldoende sprake is van regelmaat, aanmoediging, stimulering, het geven instructies en het stellen van realistische eisen aan het kind. Het stellen van grenzen en het geven van inzicht in waarom deze grenzen nodig zijn. Het uitoefenen van controle aan de ene kant, maar ook het geven van ruimte en vrijheid voor eigen wensen, initiatieven en de mogelijkheid om te experimenteren en over de structuur te onderhandelen. Het geven van verantwoordelijkheden, maar niet meer dan een kind aankan, zodat een kind binnen die grenzen kan ervaren wat de gevolgen zijn van zijn gedrag, zijn gedrag leert inschatten en af te wegen.

8. Veiligheid is een basale ontwikkelingsvoorwaarde. De ontwikkelingsvoorwaarden die in dit overzicht worden genoemd zijn van invloed op de mate waarin wordt voorzien in de veiligheidsbehoefte van het kind en dragen bij aan de positieve ontwikkeling van het kind in de toekomst.

9. Adequate voorbeelden. Hieronder wordt verstaan adequaat voorbeeldgedrag van ouders en samenleving. Het kind komt in contact met andere kinderen en volwassenen van wie het gedrag, optreden, waarden en normen kan overnemen die voor hem nu en waarschijnlijk later van belang zijn. De ouder van het kind heeft een belangrijke voorbeeldfunctie.

10. Educatie in de vorm van scholing, opleiding en de mogelijkheid om talenten te ontplooien.

11. Omgang met leeftiidgenoten. Het kind gaat om met andere kinderen in gevarieerde situaties passend bij de belevingswereld en het ontwikkelingsniveau van het kind.

12. Kennis over en contact met het verleden Het kind kent zijn levensgeschiedenis en afkomst en heeft de mogelijkheid tot het aangaan van contacten met mensen die in het verleden een belangrijke rol hebben gespeeld.

De ontwikkelingscondities zijn door mij enigszins vertaald naar de praktijk en ingekort omwille van de beperkte omvang van deze rubriek. Het overzicht is heel bruikbaar voor jeugdhulpverleners. Niet alleen in de vitleg en hulpverlening aan ouders, maar ook als wordt overwogen of een zorgmelding nodig is, of om de beslissing om een melding te doen, goed te onderbouwen. En dat hoort dan weer bij goed hulpverlenerschap. 